\title{
Application of Oxidizing Properties of Permanganate to the Determination of Famotidine in Pharmaceutical Formulations
}

\author{
Kanakapura Basavaiah* and Okram Zenita Devi
}

Department of Chemistry, University of Mysore, Manasagangothri, Mysore-570 006, India. basavaiahk@yahoo.co.in

Received February 15, 2010; accepted June 17, 2010

\begin{abstract}
One titrimetric and two spectrophotometric methods are described for the determination of famotidine (FMT) in either pure form or in its pharmaceutical formulations. The methods are based on redox reaction between FMT and $\mathrm{KMnO}_{4}$ in acid and alkaline media. In titrimetry, an acidified solution of FMT is titrated directly with permanganate. Direct spectrophotometry (method A) involves treating the alkaline solution of the drug with permanganate and measuring the bluish green product at $610 \mathrm{~nm}$. In indirect spectrophotometry $(\operatorname{method} \mathrm{B})$, the drug solution is treated with a fixed concentration of permanganate in $\mathrm{H}_{2} \mathrm{SO}_{4}$ medium, and after a specified time, the unreacted permanganate is measured at $545 \mathrm{~nm}$. The molar combining ratio in titrimetry and the optimum assay conditions are studied. Titrimetry is applicable over $1-10 \mathrm{mg}$ range and the calculations are based on a 1:3 (FMT: $\left.\mathrm{KMnO}_{4}\right)$ molar-ratio. In spectrophotometry, Beer's law is obeyed over $0.75-7.5$ and $2.5-20 \mu \mathrm{g} \mathrm{mL}^{-1}$ for method $\mathrm{A}$ and method B, respectively. The molar absorptivity values are calculated to be $2.79 \times 10^{4}$ and $1.62 \times 10^{4} \mathrm{~L} \mathrm{~mol}^{-1} \mathrm{~cm}^{-1}$ for method A and method B, respectively, and the corresponding Sandell sensitivity values are 0.012 and $0.021 \mu \mathrm{g} \mathrm{cm}^{-2}$. The limits of detection (LOD) and quantification (LOQ) are also reported for the spectrophotometric methods. The applicability of the developed methods was demonstrated by the determination of FMT in pure drug as well as in commercial dosage forms.
\end{abstract}

Keywords: Famotidine, assay, titrimetry, spectrophotometry, permanganate, pharmaceuticals.

\section{Introduction}

Famotidine (FMT), 3-[2-(diaminomethyleneamino) thiazol-4ylmethylthio]- $N$-sulfamoylpropionamidine (Fig. 1), is a histamine $\mathrm{H}_{2}$-receptor antagonist $\left(\mathrm{H}_{2}-\mathrm{RA}\right)$ which competitively inhibits the action of histamine on the $\mathrm{H}_{2}$-receptors of parietal cells and thereby reduces the gastric acid secretion under daytime and nocturnal basal conditions as well as secretion stimulated by food and pentagastrin. It is used for the short term treatment of duodenal ulcer and treatment of pathologic hypersecretory conditions like Zollinger-Ellison syndrome [1]. Therapeutic trials have shown that famotidine is approximately nine times more potent than cimetidine in inhibiting gastric acid secretion [2].

The drug is official in United State Pharmacopoeia [3] and British Pharmacopoeia [4] which describe potentiometric titrimetry and HPLC, respectively, for assay of famotidine in pharmaceutical formulations. A number of techniques have been reported for the determination of FMT in bulk, pharmaceutical dosage forms and in biological fluids and include UV-spectrophotometry [5], spectrofluorimetry [6], HPLC [7, 8], HPTLC [9, 10], capillary electrophoresis [11], differential
Resumen. Se describen tres métodos, uno de titulación y dos espectrofotométricos, para la determinación de famotidina (FMT) en su forma pura o en sus formulaciones farmacéuticas. Los métodos están basados en la reacción redox entre FMT y $\mathrm{KMnO}_{4}$ en medios ácido y básico. En el método de titulación, una solución acidificada de FMT se titula directamente con permanganato de potasio. De los métodos espectrofotométricos, el método directo A consiste del tratamiento de la solución alcalina de la droga con $\mathrm{KMnO}_{4}$ y medición del producto verde azulado a $610 \mathrm{~nm}$. En el método indirecto B, la solución de la druga se trata con una solución fija de $\mathrm{KMnO}_{4}$ en ácido sulfúrico $\mathrm{y}$, después de un tiempo específico, el $\mathrm{KMnO}_{4}$ que no reaccionó se mide a $545 \mathrm{~nm}$. Se estudió la proporción molar en el método de titulación, a fin de establecer las condiciones óptimas. Así, este método es aplicable en el intervalo de 1-10 mg, y los cálculos se basan en una proporción molar de $\mathrm{FMT} / \mathrm{KMnO}_{4}(1: 3)$. En los métodos espectrofotométricos A y B, la Ley de Beer se cumple en los intervalos de 0.757.5 y $2.5-20 \mu \mathrm{g} \mathrm{mL}^{-1}$, respectivamente. Los valores de absortividad molar se determinaron como $2.79 \times 10^{4}$ y $1.62 \times 10^{4} \mathrm{~L} \mathrm{~mol}^{-1} \mathrm{~cm}^{-1}$ para los métodos A y B, respectivamente, y los valores correspondientes de sensibilidad fueron 0.012 and $0.021 \mu \mathrm{g} \mathrm{cm}^{-2}$. Se describen igualmente los límites de detección (LOD) y cuantificación (LOQ) para los métodos espectrofotométricos. La aplicación de los métodos desarrollados se demostró en la determinación de FMT en su forma pura, así como en su forma de dosis comerciales.

Palabras clave: Famotidina, titulación, espectrofotometría, permanganato, fármacos.

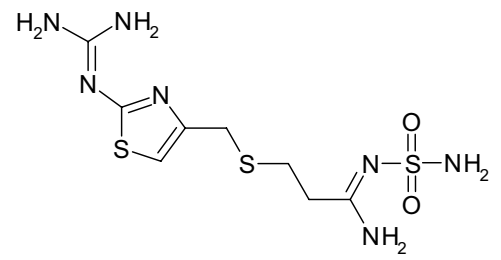

Fig. 1. Structure of famotidine.

pulse voltammetry [12] and potentiometry $[13,14]$. Some of these methods $[6-11,13]$ are no doubt sensitive and selective, but require expensive instruments and accessories and solvents besides involving several cleanup procedures [8-11].

Titrimetry and visible spectrophotometry are still considered to be very convenient and economical techniques for routine analysis of the drug in pharmaceutical formulations. The famotidine content has earlier been determined titrimetrically based on the reaction of drug with iodate [15] and chloramine$\mathrm{T}[16]$ as oxidimetric reagents. Visible spectrophotometric methods based on diverse chemical reactions have been proposed for the assay of FMT in pharmaceuticals. FMT is a good electron donor and procedures based on charge-transfer com- 
plex formation reactions with $\pi$ acceptors such as chloranil, dichlorodicyanobenzoquinone and dichloronitrophenol [17], tetracyanoquinodimethane [18] and $p$-chloranilic acid $[19,20]$ have been reported. Extractive spectrophotometric procedures [21] based on ion pair complexation reaction with bromocresol green and bromothymol blue have also been proposed. Other visible spectophotometric methods based on reactions such as complex formation with copper (II) chloride [22], cupric acetate [23], palladium (II) chloride [24], condensation reaction with ninhydrin [25], formation of orange colored product with sodium nitroprusside [26], redox reaction with NBS - paminophenol [27], reduction of Folin-Ciocalteau reagent [28] and bromination involving brominating mixture [29] are found in the literature. Most of the above visible spectrophotometric methods suffer from one or other disadvantage such as use of organic solvents [18-22, 25], poor sensitivity [17, 19-20, 22$23,26,28-29]$, poor selectivity [28], use of expensive reagents [18], use of heating step [25], narrow linear range [25, 27], close $\mathrm{pH}$ control $[21,24]$, as indicated in Table 1 . The present investigation aims to develop simple, sensitive and costeffective methods for the determination of FMT in pure form and in dosage forms using titrimetric and spectrophotometric techniques with $\mathrm{KMnO}_{4}$ as a reagent; which earlier has been used for the assay of FMT by kinetic spectrophotometry [30]. Reaction rate methods, in general, require scrupulous control of experimental variables and often known to give inaccurate and imprecise results. The present work reports the application of $\mathrm{KMnO}_{4}$ for the assay of FMT by non-kinetic titrimetric and spectrophotometric methods. Several pharmaceutical compounds have been determined through this approach using $\mathrm{KMnO}_{4}$ [31-41]. The proposed methods were demonstrated to be simple, selective and cost-effective compared to many reported methods including the official ones [3, 4].

\section{Results and discussion}

A close examination of the literature survey presented in introduction part reveals that except one kinetic spectrophotometric method, $\mathrm{KMnO}_{4}$ has not been used for the spectrophotometric determination of FMT. $\mathrm{KMnO}_{4}$ is a strong oxidizing agent and the Mn-containing products from redox reactions depend on the $\mathrm{pH}$. Acidic solutions of permanganate are reduced to the faintly pink $\left[\mathrm{Mn}\left(\mathrm{H}_{2} \mathrm{O}\right)_{6}\right]^{+2}$ and in an alkaline solution $\mathrm{KMnO}_{4}$ is spontaneously reduced to bluish-green colored $\mathrm{K}_{2} \mathrm{MnO}_{4}$, where the manganese is in the $(+6)$ oxidation state. Such oxidizing properties of $\mathrm{KMnO}_{4}$ in different $\mathrm{pH}$ conditions are applied in the present work based on which one titrimetric and two spectrophotometric methods were developed for the determination of FMT. In titrimetry, FMT is directly titrated against $\mathrm{KMnO}_{4}$ in sulphuric acid medium. And the end point was first appearance of pink color which remained for at least 2 minutes. The reaction stoichiometry was found to be $1: 3$ (FMT: $\mathrm{KMnO}_{4}$ ). The spectrophotometric methods are based on the oxidation of FMT by $\mathrm{KMnO}_{4}$ in either alkaline medium (method A) or acid medium (method B). Potassium perman- ganate quantitatively oxidizes FMT in the $\mathrm{NaOH}$ medium and gets reduced to manganate ion - the bluish green colored chromogen $[43,44]$ which exhibited strong absorption maximum at $610 \mathrm{~nm}$ (Fig. 2). The increase in absorbance was measured at $610 \mathrm{~nm}(\operatorname{method} \mathrm{A})$. In method B, the residual oxidant was measured at $545 \mathrm{~nm}$ after the reaction with FMT was ensured to be complete. In all the methods, the amount of $\mathrm{KMnO}_{4}$ reacted corresponds to the amount of drug which served as the basis of quantification.

\section{Optimization of variables}

The experimental variables which provided accurate and precise results were optimized. The influence of each variable involved in the assays was examined.

\section{Titrimetry}

In titrimetry, the reaction was found to be stoichiometric in $\mathrm{H}_{2} \mathrm{SO}_{4}$ medium. Reproducible and regular stoichiometry was obtained when 1.0-2.3 $\mathrm{M} \mathrm{H}_{2} \mathrm{SO}_{4}$ concentration was maintained. Hence, $5 \mathrm{~mL}$ of $5 \mathrm{M} \mathrm{H}_{2} \mathrm{SO}_{4}$ solution in a total volume of $15 \mathrm{~mL}$ was found to be the most suitable concentration for a quantitative reaction between FMT and $\mathrm{KMnO}_{4}$. The reaction stoichiometry was calculated to be 1: $3\left(\mathrm{FMT}: \mathrm{KMnO}_{4}\right)$ in the $1-10 \mathrm{mg}$ range. Below and above these limits irregular stoichiometries were obtained. Since the reaction between FMT and $\mathrm{KMnO}_{4}$ was little bit slower, the titration was carried out by the dropwise addition of $\mathrm{KMnO}_{4}$ solution and shaking vigorously during the titration, to the first appearance of pink color which persisted for 2 minutes.

\section{Spectrophotometry \\ Method A}

The experimental variables for the formation of stable and sensitive colored product were optimized. The sensitivity of the reaction was found to be influenced by the concentrations of $\mathrm{KMnO}_{4}$ and $\mathrm{NaOH}$. Optimum permanganate concentration was determined by varying the volume of $1000 \mu \mathrm{g} \mathrm{mL}^{-1}$ $\mathrm{KMnO}_{4}$ from $0.5-3.0 \mathrm{~mL}$ in a total volume of $10 \mathrm{~mL}$. It was found that as the concentration of $\mathrm{KMnO}_{4}$ increased, the

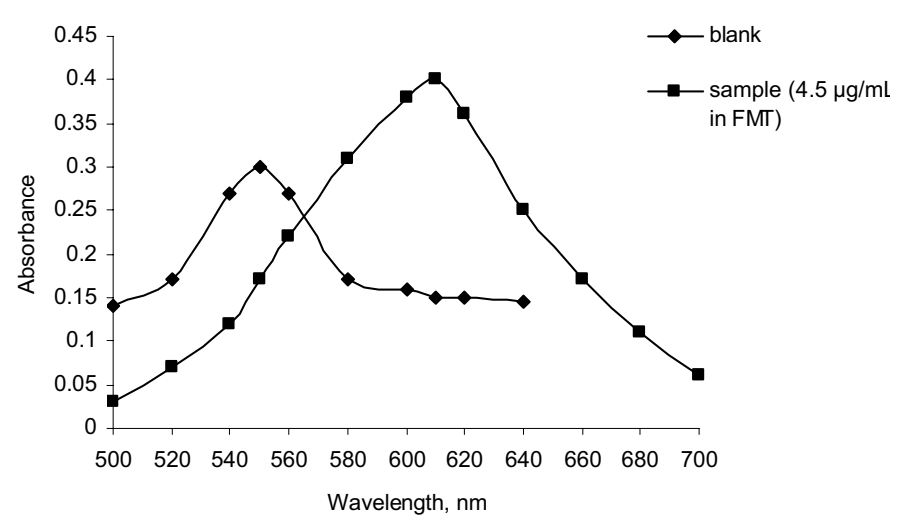

Fig. 2. Absorption spectra of method A (Bluish green color). 
Table 1. Comparison of the performance characteristic of the existing spectrophotometric methods with those of the proposed methods for the determination of FMT in pharmaceuticals.

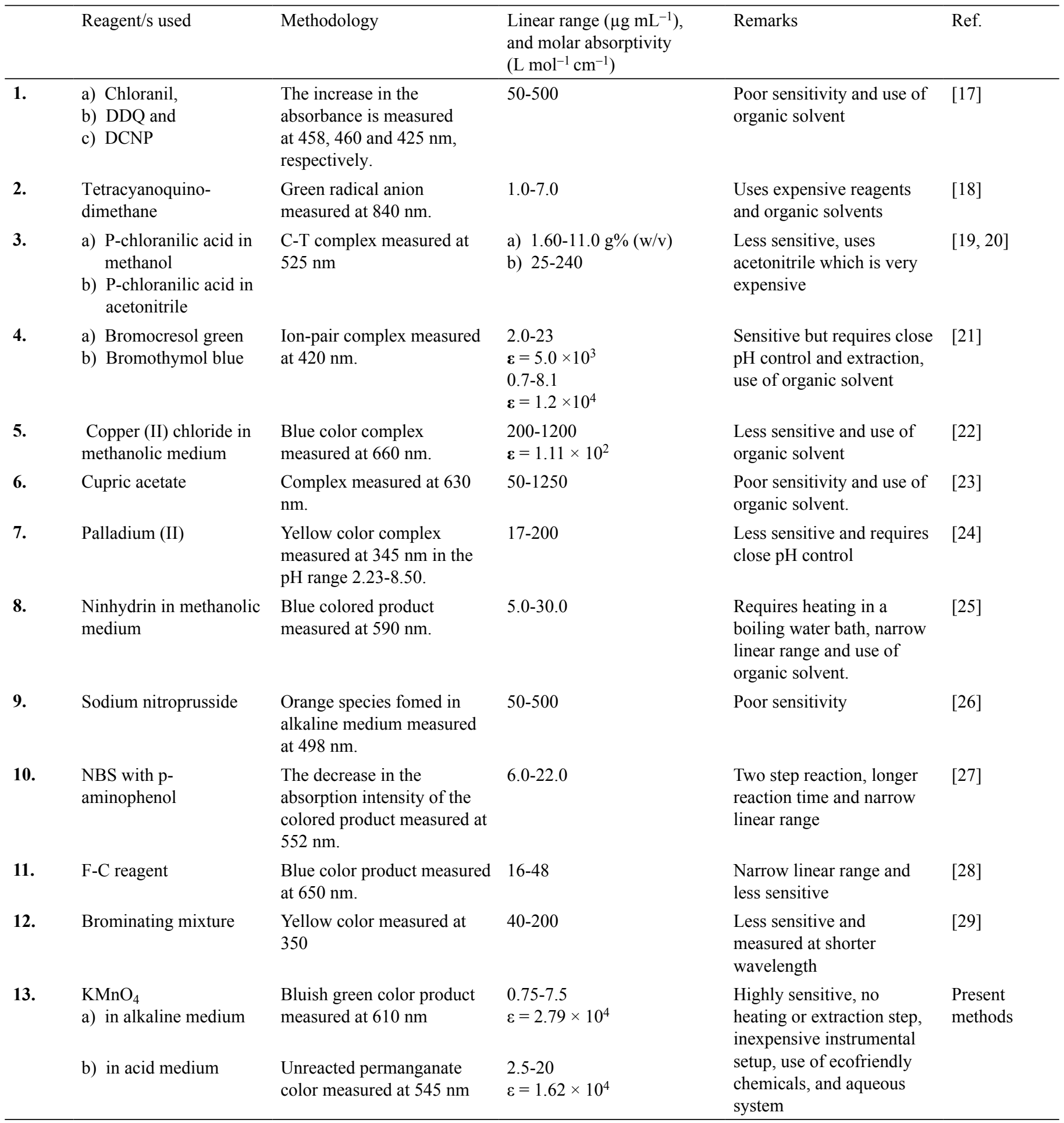

NBS: N-bromosuccinimide; FC:Folin-Ciocalteu; DDQ:dichloro dicyano benzoquinone; DCNP: dichloronitrophenol.

sensitivity of the method also increased and at the same time the respective blank absorbance also increased concomitantly (Fig. 3). In the figure, it is shown that $\Delta \mathrm{A}$ i.e. the difference in absorbance between sample and blank is more when $1 \mathrm{~mL}$ of $1000 \mu \mathrm{g} \mathrm{mL}^{-1} \mathrm{KMnO}_{4}$ was used. Hence, $1 \mathrm{~mL}$ of $1000 \mu \mathrm{g}$
$\mathrm{mL}^{-1} \mathrm{KMnO}_{4}$ in a total volume of $10 \mathrm{~mL}$ was fixed as optimum taking into consideration the sensitivity of the reaction and minimum blank absorbance. $\mathrm{NaOH}$ concentration was found to be critical as sensitivity of the reaction was found to decrease with higher $\mathrm{NaOH}$ concentrations. However, when an 


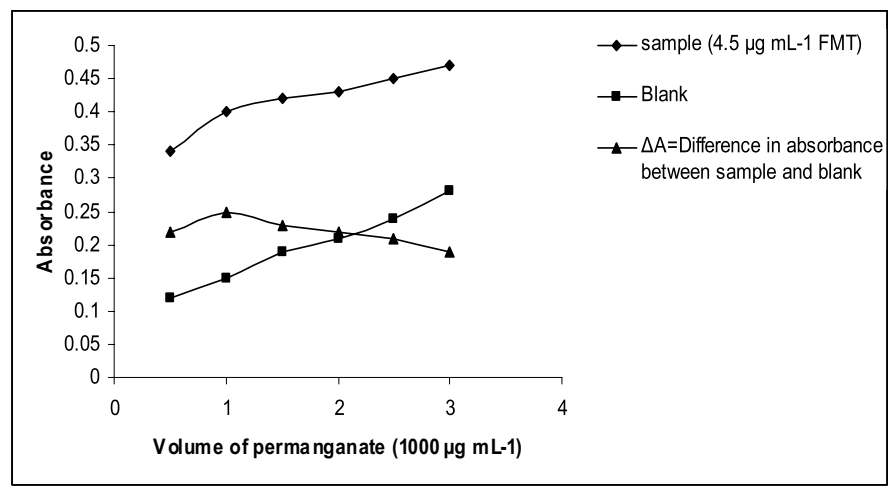

Fig. 3. Effect of $\mathrm{KMnO}_{4}$ in method A.

overall $\mathrm{NaOH}$ concentration of $0.2-0.5 \mathrm{M}$ was maintained at a drug concentration of $4.5 \mu \mathrm{g} \mathrm{mL} \mathrm{L}^{-1}$, absorbance readings were maximum and found to be almost constant (Fig. 4) and further increase $\mathrm{NaOH}$ concentration gave poor sensitivity. Hence, 1 $\mathrm{mL}$ of $3 \mathrm{M} \mathrm{NaOH}$ in a total volume of $10 \mathrm{~mL}$ was determined to be optimum for the reaction. The reaction was complete in $5 \mathrm{~min}$ and any delay up to $40 \mathrm{~min}$ had no effect on the absorbance (Fig. 5).

\section{Method B}

Preliminary experiments were performed to determine the concentration of $\mathrm{KMnO}_{4}$ which gave maximum absorbance at 545

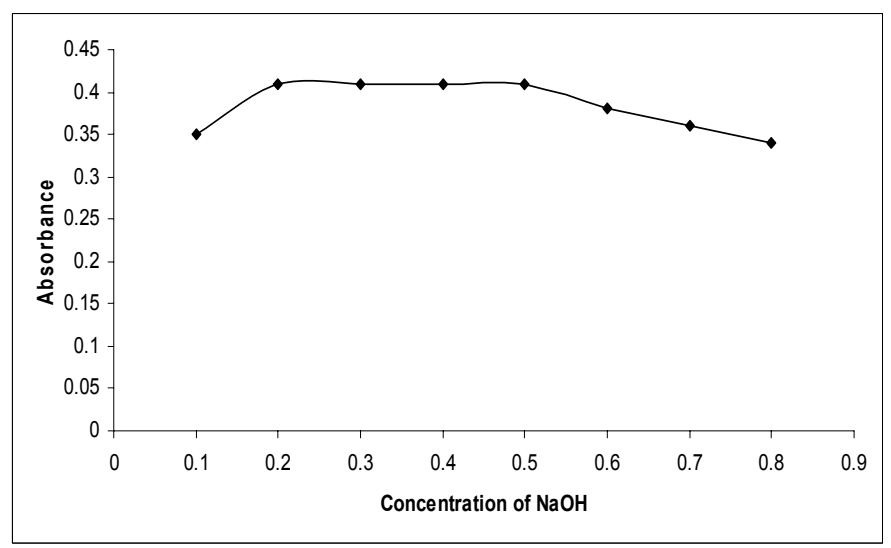

Fig. 4. Effect of $\mathrm{NaOH}$ in method $\mathrm{A}\left(4.5 \mu \mathrm{g} \mathrm{mL} \mathrm{m}^{-1}\right.$ in FMT).

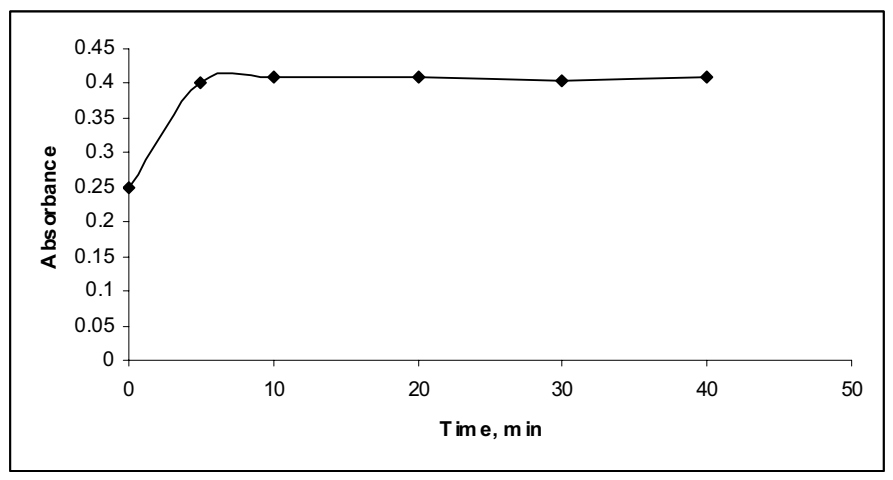

Fig. 5. Effect of time in method $\mathrm{A}\left(4.5 \mu \mathrm{g} \mathrm{mL} \mathrm{L}^{-1}\right.$ in FMT). $\mathrm{nm}$ in the acid medium employed and this was found to be 60 $\mu \mathrm{g} \mathrm{mL}^{-1}$ (Fig. 6). Sulphuric acid is the most suitable acid, since it has no action on permanganate on dilution; and with hydrochloric acid, there is the likelihood of the formation of chlorine where some permanganate may be consumed [45]. Hence, the reaction between FMT and $\mathrm{KMnO}_{4}$ was carried out in $\mathrm{H}_{2} \mathrm{SO}_{4}$ medium. When a fixed concentration of permanganate was reacted with increasing concentrations of FMT in $\mathrm{H}_{2} \mathrm{SO}_{4}$ medium, there occurred a concomitant fall in the concentration of permanganate as shown by the decreasing absorbance at $545 \mathrm{~nm}$ (Fig. 7). Hence, different concentrations of FMT were reacted with $1 \mathrm{~mL}$ of $600 \mu \mathrm{g} \mathrm{mL}^{-1}$ to determine the concentration range over which FMT could be determined. To investigate the effect of $\mathrm{H}_{2} \mathrm{SO}_{4}$ concentration on the reaction , 0.5-4.0 $\mathrm{mL}$ of $5 \mathrm{M} \mathrm{H}_{2} \mathrm{SO}_{4}$ were added to a fixed concentration of FMT $\left(10 \mu \mathrm{g} \mathrm{mL}^{-1}\right)$ and $\mathrm{KMnO}_{4}\left(60 \mu \mathrm{g} \mathrm{mL}^{-1}\right)$, and it was observed that constant absorbance readings were obtained when 1.0-3.0 $\mathrm{mL}$ of $5 \mathrm{M} \mathrm{H}_{2} \mathrm{SO}_{4}$ in a total volume of $10 \mathrm{~mL}$ were used (Fig. 8). Hence, $2 \mathrm{~mL}$ of $5 \mathrm{M} \mathrm{H}_{2} \mathrm{SO}_{4}$ was fixed. The reaction was found to be complete and quantitative when the reaction mixture was allowed to stand for $15 \mathrm{~min}$, and beyond this standing time and up to 30 minutes, the absorbance remained constant (Fig. 9).

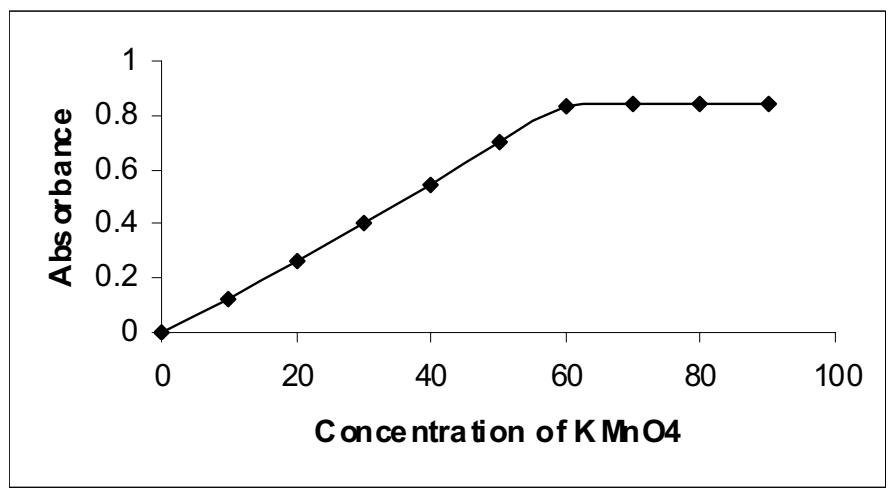

Fig. 6. Effect of $\mathrm{KMnO}_{4}(\operatorname{method} \mathrm{B})$.

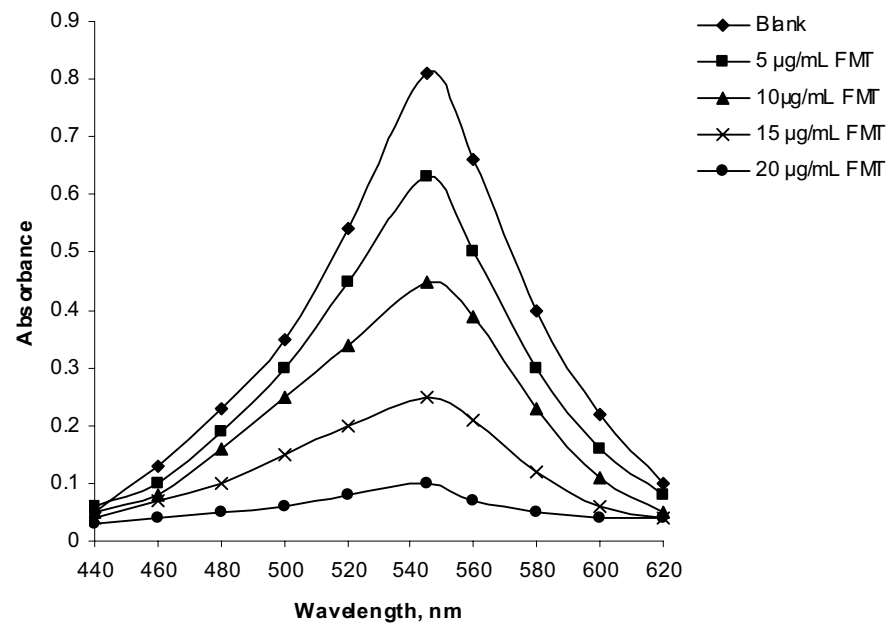

Fig. 7. Effect of FMT concentration on the absorbance of $60 \mu \mathrm{g} \mathrm{mL}-1$ $\mathrm{KMnO}_{4}$ (Method B). 


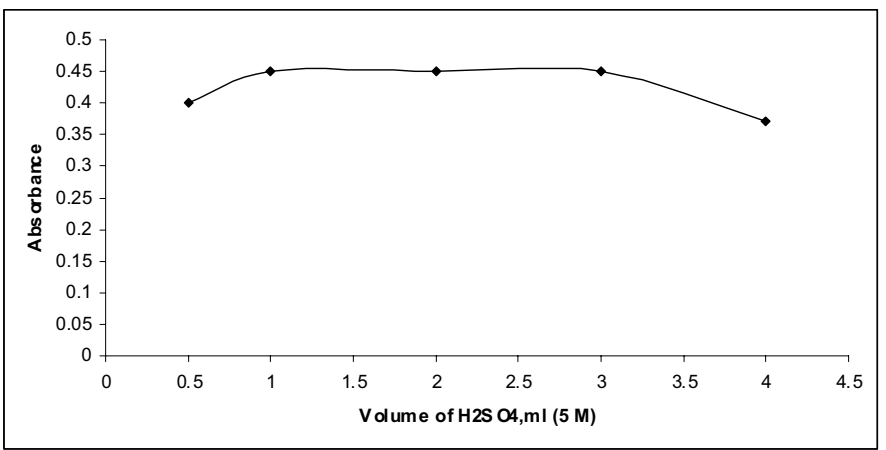

Fig. 8. Effect of $\mathrm{H}_{2} \mathrm{SO}_{4}$ in method $\mathrm{B}\left(10 \mu \mathrm{g} \mathrm{mL}^{-1}\right.$ in FMT).

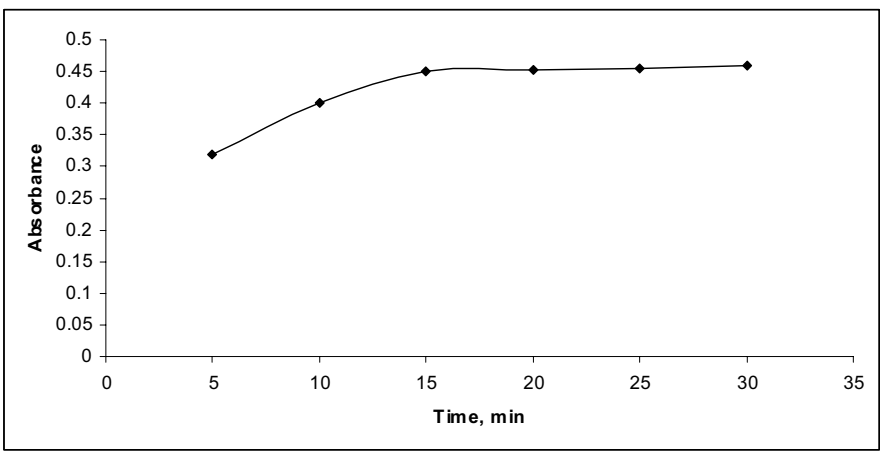

Fig. 9. Effect of time in method $\mathrm{B}\left(10 \mu \mathrm{g} \mathrm{mL}^{-1}\right.$ in FMT $)$.

\section{Method validation}

Analytical parameters of spectrophotometric methods

A linear relation was found to exist between absorbance and the concentration of FMT in the ranges of (0.75-7.5) $\mu \mathrm{g} \mathrm{mL}^{-1}$ in method A (Fig. 10a) and (2.5-20) $\mu \mathrm{g} \mathrm{mL}^{-1}$ in method B (Fig. $10 \mathrm{~b})$. The calibration graphs are described by the equation:

$$
Y=\mathrm{a}+\mathrm{b} X
$$

(Where $Y=$ absorbance, $\mathrm{a}=$ intercept, $\mathrm{b}=$ slope and $X=$ concentration in $\mu \mathrm{g} \mathrm{mL}^{-1}$ ) obtained by the method of least squares. Correlation coefficient, intercept and slope for the calibration data are summarized in Table 2 . Sensitivity parameters such as apparent molar absorptivity and Sandell sensitivity values, the limits of detection and quantification calculated as per the current ICH guidelines [46] are compiled in Table 2 and are

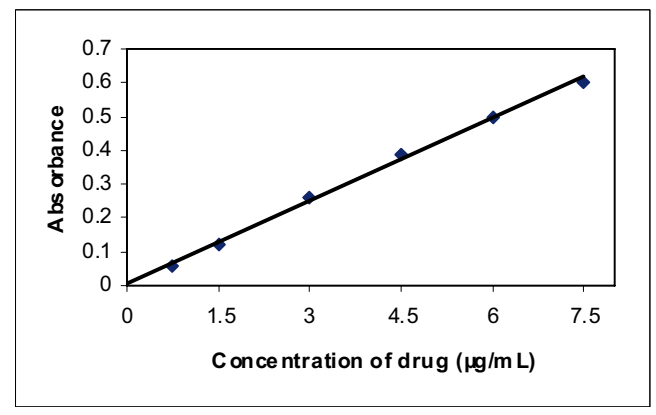

Fig. 10a. Calibration curve (method A).
Table 2. Sensitivity and Regression Parameters.

\begin{tabular}{lll}
\hline Parameter & Method A & Method B \\
\hline$\lambda_{\text {max }}, \mathrm{nm}$ & 610 & 545 \\
Linear range, $\mu \mathrm{g} \mathrm{mL}^{-1}$ & $0.75-7.5$ & $2.5-20$ \\
Molar absorptivity $(\varepsilon), \mathrm{L} \mathrm{mol}^{-1} \mathrm{~cm}^{-1}$ & $2.79 \times 10^{4}$ & $1.62 \times 10^{4}$ \\
Sandell sensitivity $^{\mathrm{a}}, \mu \mathrm{g} \mathrm{cm}{ }^{-2}$ & 0.012 & 0.021 \\
Limit of detection (LOD), $\mu \mathrm{g} \mathrm{mL}^{-1}$ & 0.06 & 0.22 \\
Limit of quantification (LOQ), $\mu \mathrm{g} \mathrm{mL}^{-1}$ & 0.17 & 0.65 \\
Regression equation, $\mathrm{Y}^{\mathrm{b}}$ & & \\
Intercept (a) & 0.007 & 0.81 \\
Slope (b) & 0.08 & 0.04 \\
Standard deviation of a $\left(\mathrm{S}_{\mathrm{a}}\right)$ & 0.03 & 0.126 \\
Standard deviation of $\mathrm{b}\left(\mathrm{S}_{\mathrm{b}}\right)$ & 0.004 & 0.008 \\
Regression coefficient $(\mathrm{r})$ & 0.998 & 0.999 \\
\hline
\end{tabular}

${ }^{\mathrm{a}}$ Limit of determination as the weight in $\mu \mathrm{g}$ per $\mathrm{mL}$ of solution, which corresponds to an absorbance of $\mathrm{A}=0.001$ measured in a cuvette of cross-sectional area $1 \mathrm{~cm}^{2}$ and $1=1 \mathrm{~cm} .{ }^{b} Y=\mathrm{a}+\mathrm{b} X$, where $Y$ is the absorbance, $X$ is concentration in $\mu \mathrm{g} \mathrm{mL}^{-1}$, a is intercept, $\mathrm{b}$ is slope.

indicative of the excellent sensitivity of both methods. The limits of detection (LOD) and quantification (LOQ) were calculated according to the same guidelines using the formulae:

$$
\mathrm{LOD}=3.3 \sigma / \mathrm{s} \text { and } \mathrm{LOQ}=10 \sigma / \mathrm{s}
$$

where $\sigma$ is the standard deviation of five reagent blank determinations and $\mathrm{s}$ is the slope of the calibration curve.

\section{Accuracy and precision}

The accuracy and precision of the methods were evaluated by performing seven replicate analyses on pure drug solution at three different amount/concentration levels (within the working ranges). The relative error (\%), an indicator of accuracy was within 3.0 and within day precision, also called the repeatability, expressed as relative standard deviation (RSD \%) was less than 2.0 indicating high accuracy and repeatability of the methods. The results of the study are given in Table 3 . The reproducibility of the methods also known as the day-to-day precision was evaluated by performing replicate analyses on pure drug solution at three levels over a period of five days,

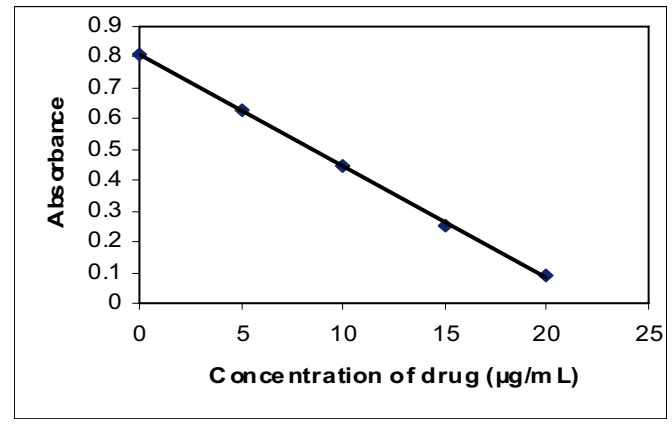

Fig. 10b. Calibration curve (method B). 
Table 3. Evaluation of intra-day and inter-day accuracy and precision.

\begin{tabular}{|c|c|c|c|c|c|c|c|}
\hline \multirow[t]{2}{*}{ Method $^{\mathrm{a}}$} & \multirow[t]{2}{*}{ FMT taken } & \multicolumn{3}{|c|}{ Intra-day accuracy and precision } & \multicolumn{3}{|c|}{ Inter-day accuracy and precision } \\
\hline & & FMT found & $\% \mathrm{RE}$ & $\%$ RSD & FMT found & $\% \mathrm{RE}$ & $\%$ RSD \\
\hline \multirow[t]{2}{*}{ Titrimetry } & 2.0 & 2.03 & 1.50 & 1.13 & 2.05 & 2.50 & 1.27 \\
\hline & 6.0 & 6.08 & 1.33 & 1.05 & 6.13 & 2.16 & 1.17 \\
\hline \multirow{2}{*}{$\begin{array}{l}\text { Spectrophotmetry } \\
\text { Method A }\end{array}$} & 1.5 & 1.53 & 2.01 & 1.14 & 1.55 & 3.33 & 1.19 \\
\hline & 7.5 & 7.35 & 2.00 & 0.89 & 7.75 & 3.33 & 1.23 \\
\hline \multirow[t]{3}{*}{ Method B } & 5.0 & 4.95 & 1.00 & 1.13 & 4.87 & 2.60 & 1.35 \\
\hline & 10.0 & 9.75 & 2.50 & 1.05 & 9.7 & 3.00 & 1.26 \\
\hline & 15 & 14.7 & 2.00 & 0.97 & 14.42 & 3.86 & 1.16 \\
\hline
\end{tabular}

RE: Relative error and RSD: Relative standard deviation.

${ }^{\mathrm{a}}$ In titrimetry, FMT taken/found are in $\mathrm{mg}$ and they are $\mu \mathrm{g} \mathrm{mL}^{-1}$ in spectrophotometry.

preparing all solutions afresh. The day-to-day RSD values were less than $2 \%$ reflecting the usefulness of the methods in routine analysis.

\section{Robustness and ruggedness}

Method robustness was tested by making small incremental change in $\mathrm{H}_{2} \mathrm{SO}_{4}$ concentration in titrimetry and in spectrophotometry, $\mathrm{H}_{2} \mathrm{SO}_{4}$ and $\mathrm{NaOH}$ concentrations and reaction time were altered. To check the ruggedness, analysis was performed by four different analysts; and on three different spectrophotometers by the same analyst. The robustness and the ruggedness were checked at three different drug levels. The intermediate precision, expressed as percent RSD, which is a measure of robustness and ruggedness was within the acceptable limits as shown in the Table 4.

\section{Effect of interferences}

The effect of interferences was tested by placebo blank and synthetic mixture analyses. In titrimetry and spectrophotometric method B, there was no interference by the inactive ingredients. In method A, as most of the organic compounds react with permanganate in alkaline medium $[47,48]$, the results showed positive interference. However, the interference was successfully overcome by extraction with acetone as described under "experimental".

The analysis of synthetic mixture solution yielded percent recoveries which ranged between 94.01 and 96.74 with standard deviation of 1.18-1.43 in all the cases. The results of this study are presented in Table 5 indicating that the inactive ingredients did not interfere in the assay. These results further demonstrate the accuracy as well as the precision of the proposed methods.

Table 4. Robustness and ruggedness expressed as intermediate precision (\%RSD).

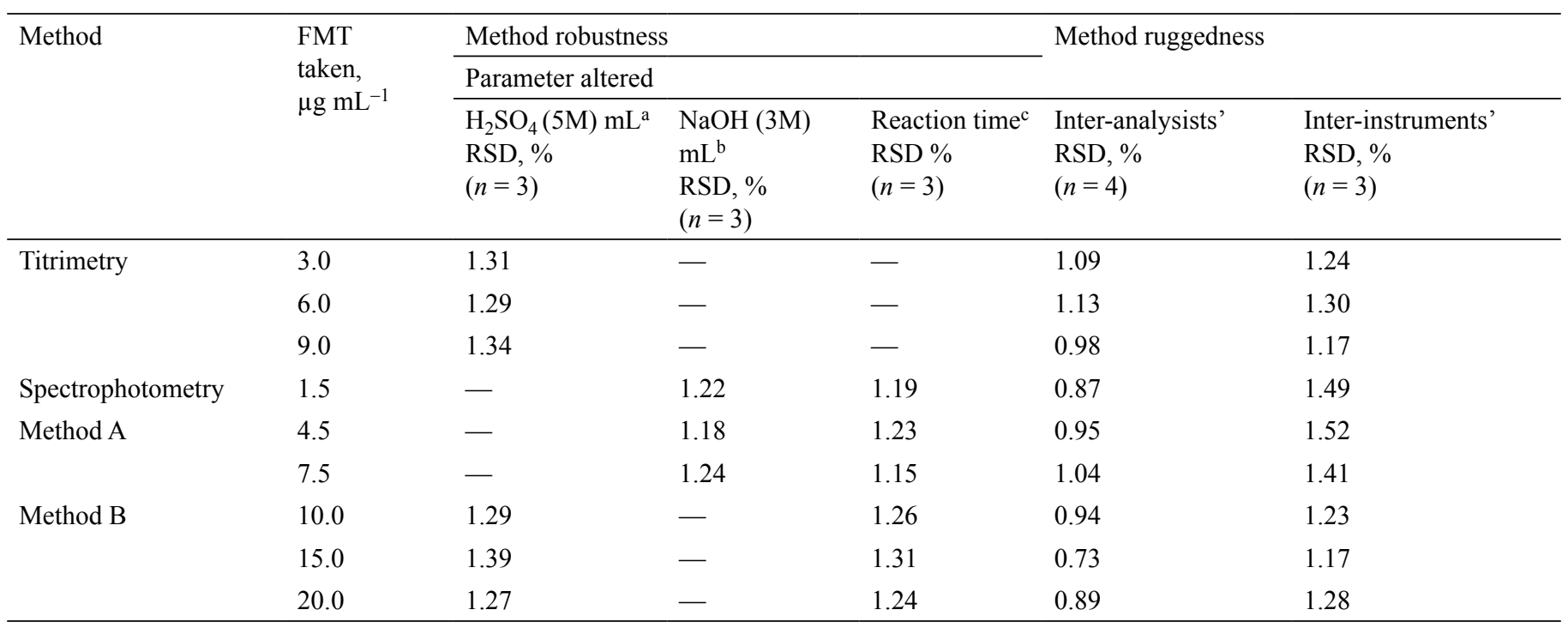

${ }^{\mathrm{a}} \mathrm{H}_{2} \mathrm{SO}_{4}$ volumes used were $4.8,5.0$ and $5.2 \mathrm{~mL}$ in titrimetry and $1.8,2.0$ and $2.2 \mathrm{~mL}$ in spectrophotometric method $\mathrm{B}$. ${ }^{\mathrm{b}} \mathrm{NaOH}$ volumes used in spectrophotometric method A were $0.8,1.0$ and $1.2 \mathrm{~mL}$. ${ }^{\mathrm{C}}$ Reaction time of 3, 5 and $7 \mathrm{~min}$ in spectrophotometric method A and 13,15 and 17 min in spectrophotometric method B were employed 
Table 5. Recovery of the drug from synthetic mixture.

\begin{tabular}{lll}
\hline Method & $\begin{array}{l}\text { FMT in synthetic } \\
\text { mixture taken }^{\mathrm{a}}\end{array}$ & $\begin{array}{l}\text { FMT recoverd } \\
\text { (Percent } \pm \text { SD) }^{\mathrm{b}}\end{array}$ \\
\hline Titrimetry & 3.0 & $95.41 \pm 1.21$ \\
& 6.0 & $96.17 \pm 1.25$ \\
Spectrophotometry & 9.0 & $96.74 \pm 1.18$ \\
Method A & 1.5 & $94.01 \pm 1.17$ \\
& 4.5 & $95.83 \pm 1.32$ \\
Method B & 7.5 & $94.78 \pm 1.43$ \\
& 10.0 & $95.70 \pm 1.34$ \\
& 15.0 & $96.68 \pm 1.21$ \\
& 20.0 & $95.82 \pm 1.18$ \\
\hline
\end{tabular}

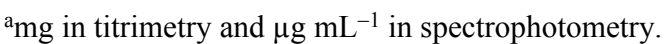

${ }^{b}$ Mean value of five determinations.

\section{Application}

Commercial tablets were successfully analyzed by the proposed methods. Co-formulated substances did not interfere in titrimetry and spectrophotometric method B. As huge interference was encountered in method A, FMT should be separated from the sample matrix by extraction with acetone and the drug reconstituted in $\mathrm{NaOH}$ before applying the procedure for assay as described under "experimental". This extraction step was found necessary to overcome the interference by the inactive organic ingredients in alkaline medium. For the purpose of comparison, the same batch pharmaceutical preparations were simultaneously analyzed by the reference method [2] which involved the titration of FMT in glacial acetic acid with $0.1 \mathrm{~N}$ perchloric acid to potentiometric end point detection. The results are presented in Table 6. As shown in the table, the results of analysis obtained by the proposed methods are in accordance with those obtained by the reference method. The performance of the methods was further judged by applying Student's t-test for accuracy and F-test for precision. At the 95\% confidence level, the calculated $\mathrm{t}$ - and F-values did not exceed the tabulated values $(t=2.77$ and $F=6.39)$ suggesting that the proposed methods are as accurate and precise as the reference method.

\section{Recovery studies}

The accuracy and validity of the proposed methods were further ascertained by performing recovery studies. Preanalysed tablet powder was spiked with pure FMT at three levels (50, 100 and $150 \%$ of that found in tablet powder) and the total was determined by the proposed methods. The percent recovery of pure FMT added ranged between 96.59 and $98.67 \%$ with standard deviation of 1.17-1.33 (Table 7) indicating that the recovery was good, and that the co-formulated substance did not interfere in the determination.

\section{Conclusions}

The proposed methods are based on well established and characterized redox reactions. The titrimetric method is straightforward and fast when compared to the other methods reported earlier. Unlike most currently available spectrophotometric methods, the present methods are free from unwelcome steps such as heating or extraction and also from critical $\mathrm{pH}$ conditions. The spectrophotometric method B has high tolerance limit for common excipients found in tablet formulations and the interference encountered in method A could be easily overcome by extraction of FMT with acetone. An important advantage is the cost-effectiveness, since analysis can be performed with an inexpensive instrument along with eco-friendly chemicals in aqueous medium. Hence, the recommended procedures are well suited for the assay and evaluation of drug in pharmaceutical industrial quality control.

\section{Experimental}

Apparatus: All absorbance measurements were made on a Systronics model 106 digital spectrophotometer (Ahmedabad, India) provided with $1-\mathrm{cm}$ matched quartz cells.

Materials and reagents: All chemicals and reagents used were of analytical or pharmaceutical grade and distilled water was used throughout the experiment.

Table 6. Results of analysis of tablets by the proposed methods.

\begin{tabular}{|c|c|c|c|c|c|}
\hline \multirow[t]{3}{*}{ Tablet Brand name } & \multirow{3}{*}{$\begin{array}{l}\text { Label claim, } \\
\text { mg/tablet }\end{array}$} & \multicolumn{4}{|c|}{ Found $^{\mathrm{a}}($ Percent of label claim \pm SD) } \\
\hline & & \multirow[t]{2}{*}{ Reference method } & \multirow[t]{2}{*}{ Titrimetry } & \multicolumn{2}{|c|}{ Spectrophotometry } \\
\hline & & & & Method A & Method B \\
\hline Famocid-20 ${ }^{\mathrm{c}}$ & 20 & $98.14 \pm 1.02$ & $\begin{array}{l}96.56 \pm 1.23 \\
t=2.22 \\
F=1.45\end{array}$ & $\begin{array}{l}96.35 \pm 1.19 \\
t=2.56 \\
F=1.36\end{array}$ & $\begin{array}{l}95.87 \pm 1.05 \\
t=2.39 \\
F=1.06\end{array}$ \\
\hline
\end{tabular}

aMean value of five determinations.

${ }^{\mathrm{b}}$ Torrent Pharmaceuticals Ltd., H. P, India; 'Sun Pharmaceuticals Industries, Jammu, India.

The value of $\mathrm{t}$ (tabulated) at $95 \%$ confidence level and for four degrees of freedom is 2.77 .

The value of $\mathrm{F}$ (tabulated) at $95 \%$ confidence level and for four degrees of freedom is 6.39 . 
Table 7. Accuracy assessment by recovery experiments.

\begin{tabular}{|c|c|c|c|c|c|}
\hline Method & Tablet studied & FMT in tablet ${ }^{\mathrm{a}}$ & Pure FMT added ${ }^{\mathrm{a}}$ & Total found ${ }^{\mathrm{a}}$ & $\begin{array}{l}\text { Pure FMT recovered } \\
\text { Percent } \pm \text { SD }\end{array}$ \\
\hline \multirow[t]{2}{*}{ Titrimetry } & \multirow[t]{2}{*}{ Topcid-20 } & 4.0 & 2.0 & 5.95 & $97.50 \pm 1.29$ \\
\hline & & 4.0 & 6.0 & 9.83 & $97.17 \pm 1.18$ \\
\hline $\begin{array}{l}\text { Spectrophotometry } \\
\text { Method A }\end{array}$ & Topcid-20 & 3.0 & 1.5 & 4.48 & $98.67 \pm 1.25$ \\
\hline \multirow[t]{3}{*}{ Method B } & \multirow[t]{3}{*}{ Topcid-20 } & 5.0 & 2.5 & 7.43 & $97.20 \pm 1.31$ \\
\hline & & 5.0 & 5.0 & 9.83 & $96.59 \pm 1.28$ \\
\hline & & 5.0 & 7.5 & 12.27 & $96.93 \pm 1.22$ \\
\hline
\end{tabular}

amg in titrimetry and $\mu \mathrm{g} \mathrm{mL}^{-1}$ in spectrophotometry.

${ }^{b}$ Mean value of three measurements.

\section{Standard FMT solution}

Pharmaceutical grade FMT certified to be $99.98 \%$ pure was received as gift from Cipla India Ltd, Mumbai, India, and used as received. Standard FMT solutions $\left(1 \mathrm{mg} \mathrm{mL}^{-1}, 15 \mu \mathrm{g} \mathrm{mL}^{-1}\right.$ and $50 \mu \mathrm{g} \mathrm{mL}^{-1}$ ) were prepared by dissolving calculated quantity of pure drug in $0.1 \mathrm{M} \mathrm{H}_{2} \mathrm{SO}_{4}$ for titrimetry and spectrophotometric method $\mathrm{B}$ and in $0.1 \mathrm{M} \mathrm{NaOH}$ for spectrophotometric method A.

Two brands of tablets containing FMT, Topcid-20 (Torrent Pharmaceuticals Ltd., H. P, India) and Famocid-20 (Sun Pharmaceuticals Industries, Jammu, India), used in the investigation were purchased from local commercial sources.

Potassium permanganate $\left(0.01 \mathrm{M}, 1000 \mu \mathrm{g} \mathrm{mL}^{-1}\right.$ and 600 $\left.\mu \mathrm{g} \mathrm{mL}^{-1}\right)$.

An approximately $0.01 \mathrm{M}$ solution was prepared by dissolving $790 \mathrm{mg}$ of $\mathrm{KMnO}_{4}$ (Merck, Mumbai, India) in water and diluting to $500 \mathrm{~mL}$ in a calibrated flask, and standardized using H.A Bright's procedure [42] and used in titrimetry. This solution was then diluted appropriately with water to get 1000 and $600 \mu \mathrm{g} \mathrm{mL}^{-1}$ working concentrations for spectrophotometric method $\mathrm{A}$ and method $\mathrm{B}$, respectively.

Sulphuric acid (5 M and 0.1 M)

Concentrated acid (S.D. Fine Chem, Mumbai, India, sp. gr. 1.84) was appropriately diluted with water to get the required concentrations.

Sodium hydroxide (3 M and $0.1 \mathrm{M}$ )

Prepared by dissolving calculated quantity of the chemical (Merck, Mumbai, India) in water.

\section{Recommended procedures}

\section{Titrimetry}

Different volumes (1-10 mL) of standard solution containing 1 $\mathrm{mg} \mathrm{mL}^{-1}$ FMT were taken in a $100 \mathrm{~mL}$ titration flask and the volume was made up to $10 \mathrm{~mL}$ with $0.1 \mathrm{M} \mathrm{H}_{2} \mathrm{SO}_{4}$. Five $\mathrm{mL}$ of $5 \mathrm{M} \mathrm{H}_{2} \mathrm{SO}_{4}$ were added and the content titrated against 0.01 $\mathrm{M} \mathrm{KMnO}_{4}$. The titration was performed by drop wise addition of $\mathrm{KMnO}_{4}$ with continuous shaking, and the end point was the first appearance of pink color which persisted for at least 2 minutes.

The amount of FMT in the aliquot was computed from the following formula:

$$
\text { Amount }(\mathrm{mg})=\mathrm{VM}_{\mathrm{w}} \mathrm{S} / \mathrm{n}
$$

where $\mathrm{V}=\mathrm{mL}$ of $\mathrm{KMnO}_{4}$ consumed

$\mathrm{M}_{\mathrm{w}}=$ relative molecular mass of drug

$\mathrm{S}=$ strength of $\mathrm{KMnO}_{4}$, moles/L

$\mathrm{n}=$ number of moles of $\mathrm{KMnO}_{4}$ reacting with per mole of FMT.

\section{Spectrophotometry}

Method A: Different aliquots of 0.5, 1.0, 2.0, 3.0, 4.0 and 5.0 $\mathrm{mL}$ of standard FMT solution $\left(15 \mu \mathrm{g} \mathrm{mL}^{-1}\right)$ were transferred into a series of $10 \mathrm{~mL}$ standard volumetric flasks and the total volume in each flask was adjusted to $5 \mathrm{~mL}$ with $0.1 \mathrm{M} \mathrm{NaOH}$. To each flask, $1 \mathrm{~mL}$ of $3 \mathrm{M} \mathrm{NaOH}$ followed by $1 \mathrm{~mL}$ of 1000 $\mu \mathrm{g} \mathrm{mL}^{-1} \mathrm{KMnO}_{4}$ were added. The content of each flask was mixed well and kept aside for 5 minutes with occasional shaking. The volume was made up to the mark with distilled water and the absorbance was measured at $610 \mathrm{~nm} V s$ reagent blank prepared in a similar manner.

Method B: Different aliquots $(0.0,0.5,1.0,2.0,3.0$ and 4.0 $\mathrm{mL}$ ) of standard $50 \mu \mathrm{g} \mathrm{mL} \mathrm{mL}^{-1}$ FMT solution were accurately measured and transferred into a series of $10 \mathrm{~mL}$ volumetric flasks by means of a microburette and the total volume was adjusted to $5 \mathrm{~mL}$ with $0.1 \mathrm{M} \mathrm{H}_{2} \mathrm{SO}_{4}$. To each flask $2 \mathrm{~mL}$ of 5 $\mathrm{M} \mathrm{H}_{2} \mathrm{SO}_{4}$ and $1 \mathrm{~mL}$ of $600 \mu \mathrm{g} \mathrm{mL}^{-1} \mathrm{KMnO}_{4}$ were added, the latter using microburette. The content of each flask was mixed well and kept aside for 15 minutes. The volume was made up to the mark with distilled water and the absorbance was measured at $545 \mathrm{~nm} v s$ water.

Calibration graphs were prepared by plotting either the increasing absorbance values in method A or decreasing absorbance values in method B versus concentration of FMT. 
The concentration of the unknown was read from the respective calibration graph or deduced from the regression equation derived using the absorbance-concentration data.

\section{Procedure for the assay of famotidine in pharmaceutical preparations}

Twenty tablets were weighed accurately and ground into a fine powder. An accurately weighed amount of the powdered tablet equivalent to $100 \mathrm{mg}$ of FMT was transferred to a $100 \mathrm{~mL}$ calibrated flask and shaken with $60 \mathrm{~mL}$ of $0.1 \mathrm{M} \mathrm{H}_{2} \mathrm{SO}_{4}$ (titrimetry and spectrophotometric method $\mathrm{B}$ ) for about $20 \mathrm{~min}$, then made up to the mark with the same solvent and mixed; and filtered using a Whatman No. 42 filter paper. First $10 \mathrm{~mL}$ portion of the filtrate was discarded, and a convenient aliquot (say $5 \mathrm{~mL}$ ) was taken and the assay completed according to the titrimetric procedure described above. The tablet extract containing $1 \mathrm{mg} \mathrm{mL}-1$ FMT was then diluted stepwise with $0.1 \mathrm{M} \mathrm{H}_{2} \mathrm{SO}_{4}$ to obtain working concentration of $50 \mu \mathrm{g} \mathrm{mL}$ in FMT for spectrophotometric method B and the analysis was completed using the procedure describe above (method B). In method A, an accurately weighed amount of the powdered tablet equivalent to $5 \mathrm{mg}$ of FMT was extracted with three 10 $\mathrm{mL}$ portions of acetone by shaking for $10 \mathrm{~min}$ each time and filtered using a Whatman No. 42 filter paper. The filter paper was washed several times with small portions of acetone. The filtrate and washings were evaporated to dryness. The residue was dissolved in $0.1 \mathrm{M} \mathrm{NaOH}$ and diluted up to the mark of a $50 \mathrm{ml}$ volumetric flask. The resulting solution was diluted with $0.1 \mathrm{M} \mathrm{NaOH}$ to obtain $15 \mu \mathrm{g} \mathrm{mL}^{-1}$ in FMT and the assay was completed by following the recommended procedure (method A).

\section{Placebo blank analysis}

A placebo blank of the composition: talc $(10 \mathrm{mg})$, starch $(5$ $\mathrm{mg}$ ), acacia $(5 \mathrm{mg})$, methyl cellulose $(10 \mathrm{mg})$, sodium citrate $(5 \mathrm{mg})$, magnesium stearate $(10 \mathrm{mg})$ and sodium alginate $(5$ $\mathrm{mg}$ ) was made and its solution was prepared as described under 'Procedure for the assay of famotidine in pharmaceutical preparations', and then subjected to analysis using the procedures described above.

\section{Procedure for the determination of famotidine in synthetic mixture}

To the placebo blank of the composition described above, $100 \mathrm{mg}$ of FMT was added and homogenized, transferred to a $100 \mathrm{~mL}$ standard flask and solution prepared as described under tablets. The solution was mixed well and filtered using a Whatman No. 42 filter paper. The resulting solution was assayed $(n=5)$ by titrimetry according to the procedure described above. The synthetic mixture solution $\left(1 \mathrm{mg} \mathrm{mL}^{-1}\right.$ in FMT) was then diluted stepwise with $0.1 \mathrm{M} \mathrm{H}_{2} \mathrm{SO}_{4}$ to obtain working concentration of $50 \mu \mathrm{g} \mathrm{mL}^{-1}$ in FMT for spectrophotometric method B. A convenient aliquot was then subjected to analysis. In method A, $5 \mathrm{mg}$ of FMT was added to the placebo blank of the composition described above and homogenized and followed the same extraction procedure which was described under 'Procedure for the assay of famotidine in pharmaceutical preparations' and then subjected to analysis using the procedure described above. These analyses were performed to study the effect of excipients such as talc, starch, acacia, methyl cellulose, sodium citrate, magnesium stearate and sodium alginate on the performance of the methods.

\section{Acknowledgements}

The authors are grateful to Cipla India Ltd., Mumbai, India, for providing the gift sample of famotidine. One of the authors (OZD) is gratefully thanks to the University Grant Commission (UGC), New Delhi, India for the award of UGC Meritorious Research Fellowship.

\section{References}

1. Goodman \& Gilman's "The Pharmacological Basis of Therapeutics", 9 $9^{\text {th }}$ Ed., McGraw Hill, New York, 1996, 904.

2. Campoli-Richard, D. M.; Clissold, S. P. Drugs. 1986, 32, 197-221.

3. United State Pharmacopoeia 23, National Formulary 18, United States, Pharmacopoeial Convention, Rockville, MD, 1995, 65, 1360.

4. British Pharmacopoeia, The Stationary Office London, 1998, 572.

5. Sahu, R.; Preeti, N.; Bhattacharya, S.; Deepti, J. Indian J. Pharm. Sci. 2006, 68, 503-506.

6. Walash, M. I.; El-Brashy, A.; El-Enany, N.; Kamel, M. E. J. Fluor. 2008, 19, 333-344.

7. Zarghi, A.; Shafaati, A.; Foroutan, S. M.; Khoddam, A. J. Pharm. Biomed. Anal. 2005, 39, 677-680.

8. Mutaz, A.; Sheikh, S.; Hanan, A. N.; Adnan, B. A. Anal. Lett. 1989, 22, 2501-2510.

9. Campbell, A. N.; Sherma, J. J. Liq. Chromatogr. Rel. Technol. 2003, 26, 2719-2727.

10. Novakovic, J. J. Chromatogr. 1999, 846, 193-198.

11. Ibrahim, D. A.; Samiha, A. H.; Ashraf, M. M.; Ahmed, I. H. Int. J. Biomed. Sci. 2007, 3, 123-130.

12. Squella, J. A.; Rivera, C.; Lemus, I.; Nunez-Vergara, L. J. Microchim. Acta 1990, 100, 343-348.

13. Ayad, M.; Shalaby, A.; Hisham, E. J. M. J. Pharm. Biomed. Anal. 2002, 29, 247-254.

14. Magda, M. A.; Abdalla, S.; Hisham, E. A.; Heba, M. E. J. Pharm. Biomed. Anal. 2002, 29, 247-244.

15. Basavaiah, K.; Prameela, H. C. Bulg. Chem. Ind. 2003, 74, 50-55.

16. Basavaiah, K.; Prameela, H. C. Bulg. Chem. commun. 2003, 35, $37-42$

17. Kamath, B. V.; Shivram, K.; Saroj, V. Anal. Lett. 1992, 25, 2239-2247.

18. Sheikha Al-Ghannam, F. B. J. AOAC Int. 2002, 85, 1003-1008.

19. Chukwurah, B. K.; Ajali, U. Boll. Chim. Farm. 2001, 140, 354-360.

20. Mohammad, H. A. Bull. Pharm. Sci. (Assiut University), 2000, 23, 157-163

21. Abu Zuhri, A. Z.; Shubietah, R. M.; Badah, G. M. J. Pharm. Biomed. Anal. 1999, 21, 459-465.

22. Basavaiah, K.; Prameela, H. C. Indian Pharmacist, 2004, 3, 59-61. 
23. Guvener, B.; Ates, S. Acta Pharm. Turc 1988, 30, 67-68.

24. Zagorka, K.; Tatijana, J.; Jelena, P.; Dragica, M. J. Serb. Chem. Soc. 2004, 69, 485-491.

25. Nafisur, R.; Mohammad, K. Farmaco 2003, 58, 1045-1050.

26. Agarwal, Y. K. K.; Shivaramchandra, K.; Rao, G. N. J. Pharm. Biomed. Anal. 1992, 10, 521-523.

27. Ibrahim, A.; Darwish, S. A.; Hussein, A. M.; Mahmoud, A. H. I. Acta Pharm. 2007, 58, 87-97.

28. Rao, G. R.; Kanjilal, G.; Mohan, K. R. Analyst 1978, 103, 521-523.

29. Rami, N. R.; Prabhavathi, K.; Bhaskar, R. Y. V.; Chakravarthy, I. E. Indian J. Pharm. Sci. 2006, 68, 645-647.

30. Rahman, N.; Kashif, M. Anal. Sci. 2003, 19, 907-911.

31. Tammilehto, S. A. J. Pharm. Pharmacol. 1980, 32, 524.

32. Murugesan, A.; Venkappaya, D. Curr. Sci. 1983, 52, 249.

33. Vinay, K. B.; Revanasiddappa, H. D.; Zenita, O.; Basavaiah, K. $C I \& C E Q$ 2009, 15, 149-157.

34. Zenita, O.; Basavaiah, K.; Vinay, K. B. CI\&CEQ 2010, 16, 97-102.

35. Tharpa, K.; Basavaiah, K.; Vinay, K. B. Jordan J. Chem. 2009, 4, 387-397.

36. Basavaiah, K.; Rajendraprasad, N.; Tharpa, K.; Anilkumar, U. R.; Hiriyanna, S. G.; Vinay. K. B. J. Mex. Chem. Soc. 2009, 53, 34-40.

37. Basavaiah. K.; Tharpa, K.; Anil Kumar, U. R.; Rajendraprasad, N.; Hiriyanna, S.; Vinay, K. B. Arch. Pharm. Res. 2009, 32, 1271-1279.
38. Abdellatef, H. E. J. Pharm. Biomed. Anal. 2002, 29, 835-842.

39. Reddy, M. N.; Reddy, V. P. N.; Reddy, P. J. C.; Murthy, T. K.; Srinivasa, Y. Antiseptic 2002, 99, 88.

40. Al-Ghanman, S. M.; Belal, F. Farmaco 2001, 56, 677-681.

41. Sastry, C. S. P.; Vijaya, R. T.; Satyanarayana, A. Indian J. Pharm. Sci. 1998, 60, 55-58.

42. Bright, H. A. Vogel's Text Book of Inorganic Analysis Including Elementary Instrumental Analysis, $3^{\text {rd }}$ Ed., 1961, 280.

43. Mann, F. G.; Sounders, B.C. Int. New Impressions, $4^{\text {th }}$ Ed., Orient Longman, Cambridge, 1974, 85.

44. Sharma, B. K. Instrumental Methods of Analysis, $18^{\text {th }}$ Edn., Goel Publishing Home, Meerut, 1994, 114.

45. Basset, J.; Denney, R. C.; Jeffery, G. H.; Mendham, J. Vogel's Text Book of Inorganic Analysis Including Elementary Instrumental Analysis, $4^{\text {th }}$ Ed., 1978, 348 .

46. International Conference On Harmonisation of Technical Requirements for Registration of Pharmaceuticals for Human Use, ICH Harmonised Tripartite Guideline, Validation of Analytical Procedures: Text and Methodology Q2(R 1), Complementary Guideline on Methodology dated 06 November 1996, incorporated in November, 2005, London.

47. Kolthoff, I. M.; Belcher, R.; Stenger, V. A.; Matsuyuma, G. Volumetric Analysis, Interscience Publishers, Inc., New York, Vol. 3, 1957, 113-118.

48. Nanji, D. R.; Norman, A. G. J. Soc. Chem. Ind. (London) 1926, $45,337 \mathrm{~T}$. 